Sari Pediatri, Vol. 8, No. 3, Desember 2006: 195 - 208

\title{
Clinical Pathways Kesehatan Anak
}

\author{
Dody Firmanda
}

Clinical Pathways (CP) sebagai kunci utama untuk masuk ke dalam sistem pembiayaan yang dinamakan DRG-Casemix. Merupakan suatu konsep perencanaan pelayanan terpadu yang merangkum setiap langkah yang diberikan kepada pasien berdasarkan standar pelayanan medis dan asuhan keperawatan yang berbasis bukti dengan hasil yang terukur dan dalam jangka waktu tertentu selama di rumah sakit. Clinical Pathways merupakan salah satu komponen dari Sistem DRG-Casemix yang terdiri dari kodefikasi penyakit dan prosedur tindakan (ICD 10 dan ICD 9-CM) dan perhitungan biaya (baik secara top down costing atau activity based costing maupun kombinasi keduanya). Implementasi CP sangat erat berhubungan dan berkaitan dengan Clinical Governance dalam rangka menjaga dan meningkatkan mutu pelayanan dengan biaya yang dapat diestimasikan dan terjangkau. Dalam menyusun Format Clinical Pathways harus diperhatikan komponen yang harus dicakup sebagaimana definisi dari Clinical Pathways. Manfaatkan data yang telah ada di lapangan rumah sakit dan kondisi setempat seperti data Laporan RL1 sampai dengan RL6 dan sensus harian.Variabel varians dalam CP dapat digunakan sebagai alat (entry point) untuk melakukan audit medis dan manajemen baik untuk tingkat pertama maupun kedua ( $1^{\text {st }}$ party and $2^{\text {nd }}$ party audits) dalam rangka menjaga dan meningkatkan mutu pelayanan. Variabel tindakan dalam CP dapat digunakan sebagai alat (entry point) untuk melakukan surveilans Tim Pengendalian Infeksi Nosokomial dan selanjutnya untuk menilai Health Impact Intervention. Variabel obat obatan dalam CP dapat digunakan sebagai alat (entry point) untuk melakukan kegiatan evaluasi dan monitoring dari 5 Langkah 12 Kegiatan Tim Farmasi dan Terapi Komite Medik RS. Sekaligus secara tidak langsung menggalakkan penggunanan obat secara rasional dan dapat melihat cermin dari penggunaan obat generik. CP dapat digunakan sebagai salah satu alat mekanisme evaluasi penilaian risiko untuk mendeteksi kesalahan aktif (active errors) dan laten (latent / system errors) maupun nyaris terjadi (near miss) dalam Manajemen Risiko Klinis (Clinical Risk Management) dalam rangka menjaga dan meningkatkan keamanan dan keselamatan pasien (patient safety). Hasil dan revisi CP dapat digunakan juga sebagai alat (entry point) untuk melakukan perbaikan dan revisi Standar Pelayanan Medis dan asuhan Keperawatan yang bersifat dinamis dan berdasarkan pendekatan Evidence-based Medicine (EBM) dan Evidence-based Nurse (EBN). Partisipasi aktif, komitmen dan konsistensi dari seluruh jajaran direksi, manajemen dan profesi harus dijaga dan dipertahankan demi terlaksana dan suksesnya program Casemix di rumah sakit. Bila Sistem Casemix Rumah Sakit telah berjalan, maka untuk selanjutnya akan lebih mudah untuk masuk ke dalam sistem pembiayaan lebih lanjut yakni Health Resources Group (HRG). Peran profesi organisasi IDAI sangat strategis dan penting dalam mengembangkan SPM dan Clinical Pathways sebagai acuan pedoman bagi setiap anggota profesi dalam melaksanakan praktik keprofesiannya.

Kata kunci: Clinical Pathways, DRG-Casemix, Kondifikasi penyakit, Prosedur tindakan 
U ndang Undang Nomor 29 Tahun 2004 tentang Praktik Kedokteran dalam pasal 49 menyebutkan bahwa dalam melaksanakan praktik kedokteran wajib menyelenggarakan kendali mutu dan kendali biaya melalui kegiatan audit medis serta dilaksanakan oleh organisasi profesi. Ini merupakan salah satu dari sekian tugas berat yang diamanatkan oleh undang undang tersebut kepada organisasi profesi (dalam hal ini organisasi profesi kita adalah IDAI).

Untuk melakukan kegiatan audit medis dapat menggunakan instrumen Pedoman Audit Medis dari Departemen kesehatan RI. ${ }^{1}$

Dalam makalah ini kami berbagi pengalaman di SMF Kesehatan Anak dan Komite Medik Fatmawati Jakarta dalam rangka meningkatkan mutu profesi sebagai dokter spesialis anak di dalam satu sistem sarana pelayanan kesehatan (rumah sakit).
Komite Medik RS Fatmawati telah merancang strategi pendekatan untuk mengimplementasikan Sistem Penataan Klinis (Clinical Governance) ${ }^{2-6}$ di Rumah Sakit Fatmawati dikenal sebagai Sistem Komite Medik dan Sistem SMF$^{7}$ telah berjalan sejak tahun 2003, mengkombinasikannya dengan Sistem Pembiayaan Casemix ${ }^{8}$ melalui pendekatan mutu profesi ${ }^{9-}$ 12 yakni dengan memadukan sistem pelayanan berkesinambungan (continuing of care) - dikenal sebagai dalam bentuk Alur Penerimaan Pasien ${ }^{13,14}$ dan Kebijakan Pelayanan secara by names ${ }^{15,16}$ yang telah ada dengan Standar Pelayanan Medis dari seluruh 20 SMF ${ }^{17}$ melalui Clinical Pathways. ${ }^{6}$ (Gambar 1)

Bila ada deviasi dari isi komponen Clinical Pathways dicatat sebagai dalam kolom varians dan ditindak lanjuti sebagai variance tracking dengan menggunakan mekanisme audit medis tingkat pertama atau kedua ( $1^{\text {st }}$ and $2^{\text {nd }}$ Party Medical Audit) sesuai

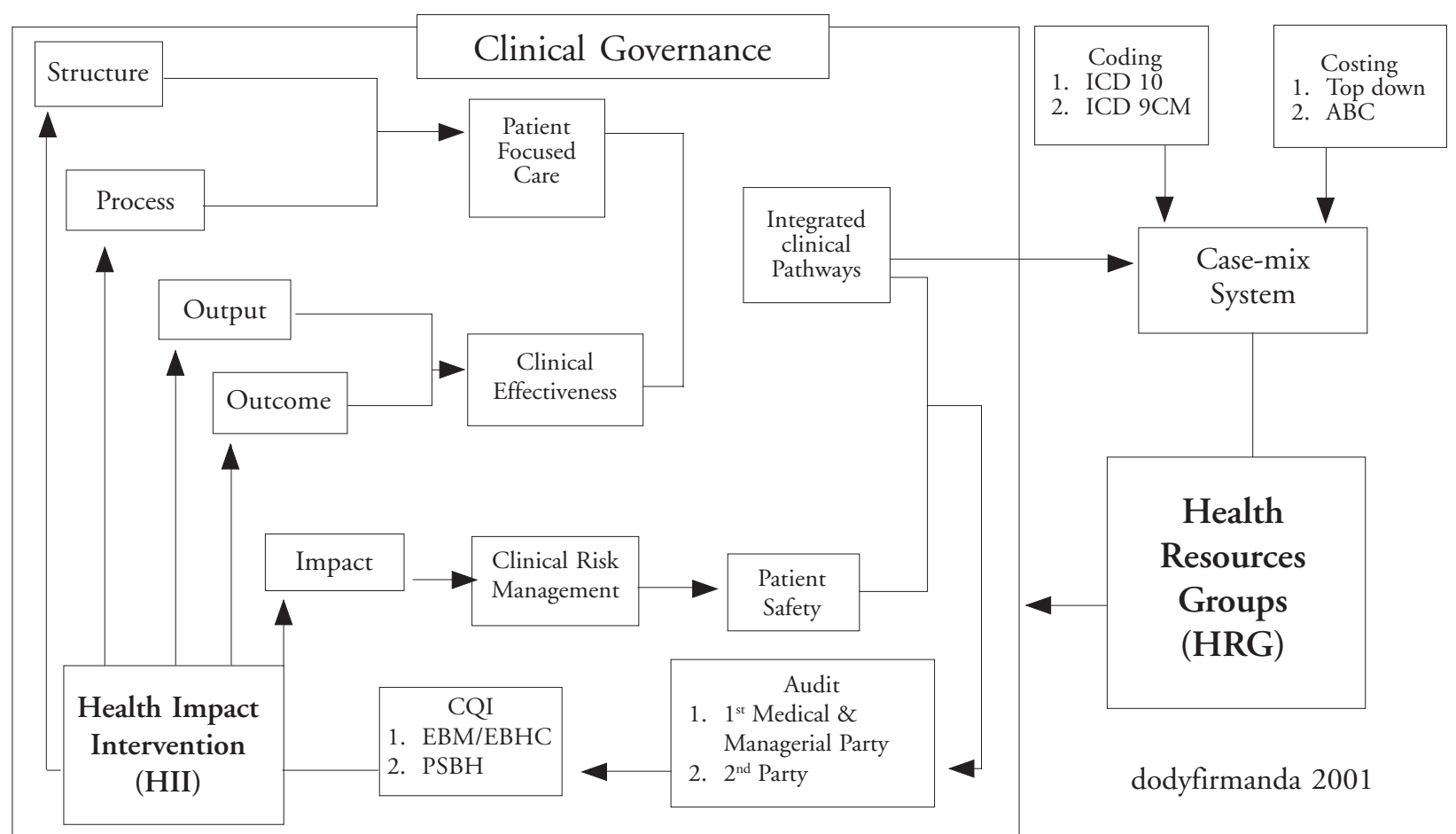

Gambar 1. Skema strategi pendekatan Komite Medik RS Fatmawati dalam Clinical Governance dan Sistem DRGs Casemix. ${ }^{6}$

\section{Alamat korespondensi:}

Dr. Dodi Firmanda, Sp.A, MA

Ketua Komite Medik Rs Fatmawati Jakarta

RS Fatmawati Jl. Raya Fatmawati Jakarta 12430

Telpon: 0217660552 ext 1532, Fax. 0217690123

E-mail: firmanda@indo.net.id dengan Pedoman Audit Medis Komite Medik RS Fatmawati ${ }^{18-21}$ dan Panduan Manajemen Risiko Klinis dan Keamanan/ Keselamatan Pasien (Clinical Risks Management and Patient Safety) Komite Medik RS 
Fatmawati ${ }^{22}$ dengan cara Root Cause Analysis (RCA), Failure Mode of Effective Analysis (FMEA) atau Probability Risks Assessment (PRA) serta Panduan Health Impact Intervention Komite Medik RS Fatmawati. ${ }^{23}$

\section{Definisi Clinical Pathways (CP)}

Clinical Pathways (CP) adalah suatu konsep perencanaan pelayanan terpadu yang merangkum setiap langkah yang diberikan kepada pasien berdasarkan standar pelayanan medis dan asuhan keperawatan yang berbasis bukti dengan hasil yang terukur dan dalam jangka waktu tertentu selama di rumah sakit. ${ }^{24-27}$

European Pathways Association (EPA) ${ }^{28}$ pada kongresnya yang terakhir di Slovenia telah merevisi definisi Clinical Pathways sebagai berikut: Clinical Pathways adalah metodologi dalam cara mekanisme pengambilan keputusan terhadap layanan pasien berdasarkan pengelompokan dan dalam periode waktu tertentu.

\section{Prinsip prinsip dalam menyusun Clinical Pathways $^{1-4}$}

Dalam membuat Clinical Pathways penanganan kasus pasien rawat inap di rumah sakit harus bersifat:

a. Seluruh kegiatan pelayanan yang diberikan harus secara terpadu/integrasi dan berorientasi fokus terhadap pasien (patient focused care) serta berkesinambungan (continuing of care)

b. Melibatkan seluruh profesi (dokter, perawat/bidan, penata, laboratoris dan farmasis)

c. Dalam batasan waktu yang telah ditentukan sesuai dengan keadaan perjalanan penyakit pasien dan dicatat dalam bentuk periode harian (untuk kasus rawat inap) atau jam (untuk kasus gawat darurat di unit emergensi).

d. Pencatatan CP seluruh kegiatan pelayanan yang diberikan kepada pasien secara terpadu dan berkesinambungan tersebut dalam bentuk dokumen yang merupakan bagian dari Rekam Medis.

e. Setiap penyimpangan langkah dalam penerapan CP dicatat sebagai varians dan dilakukan kajian analisis dalam bentuk audit.

f. Varians tersebut dapat terjadi karena kondisi perjalanan penyakit, penyakit penyerta atau komplikasi maupun kesalahan medis (medical errors) dan dipergunakan sebagai salah satu parameter dalam rangka mempertahankan dan meningkatkan mutu pelayanan.

Pada akhirnya CP dapat merupakan suatu Standar Prosedur Operasional yang merangkum: ${ }^{2-5}$

a. Profesi medis: Standar Pelayanan Medis dari setiap kelompok staf medis/staf medis fungsional (SMF) klinis dan penunjang.

b. Profesi keperawatan: asuhan keperawatan

c. Profesi farmasi: unit dose daily dan stop ordering

d. Alur Pelayanan Pasien Rawat Inap dan Operasi dari Sistem Kelompok Staf Medis/Staf Medis Fungsional (SMF), Instalasi dan Sistem Manajemen Rumah Sakit.

\section{Langkah langkah penyusunan Clinical Pathways $^{2-5}$}

Langkah langkah dalam menyusun Format CP yang harus diperhatikan:

1. Komponen yang harus dicakup sebagaimana definisi dari Clinical Pathways

2. Manfaatkan data yang telah ada di lapangan rumah sakit dan kondisi setempat ${ }^{24}$ seperti data Laporan RL2 (data keadaan morbiditas pasien) yang dibuat setiap rumah sakit berdasarkan Buku Petunjuk Pengisian, Pengolahan dan Penyajian Data Rumah Sakit $^{30}$ dan sensus harian untuk penetapan judul/ topik Clinical Pathways yang akan dibuat dan penetapan lama hari rawat.

3. Untuk variabel tindakan dan obat obatan mengacu kepada Standar Pelayanan Medis, Standar Prosedur Operasional dan Daftar Standar Formularium yang telah ada di rumah sakit setempat. Bila perlu standar-standar tersebut dapat dilakukan revisi. ${ }^{2,5,7}$

4. Pergunakan Buku ICD 10 untuk hal kodefikasi diagnosis dan ICD 9 CM untuk hal tindakan prosedur sesuai dengan profesi/SMF masing masing. ${ }^{26}$

\section{Penjelasan Penyusunan Format Clinical Pathways}

\section{Ilustrasi Contoh}

Sebagai contoh ilustrasi pengalaman Komite Medik RS Fatmawati dalam rangka penyusunan dan implementasi Sistem Casemix rumah sakit sebagai upaya meningkatkan kinerja dan mutu profesi. 


\section{Format Umum Clinical Pathways}

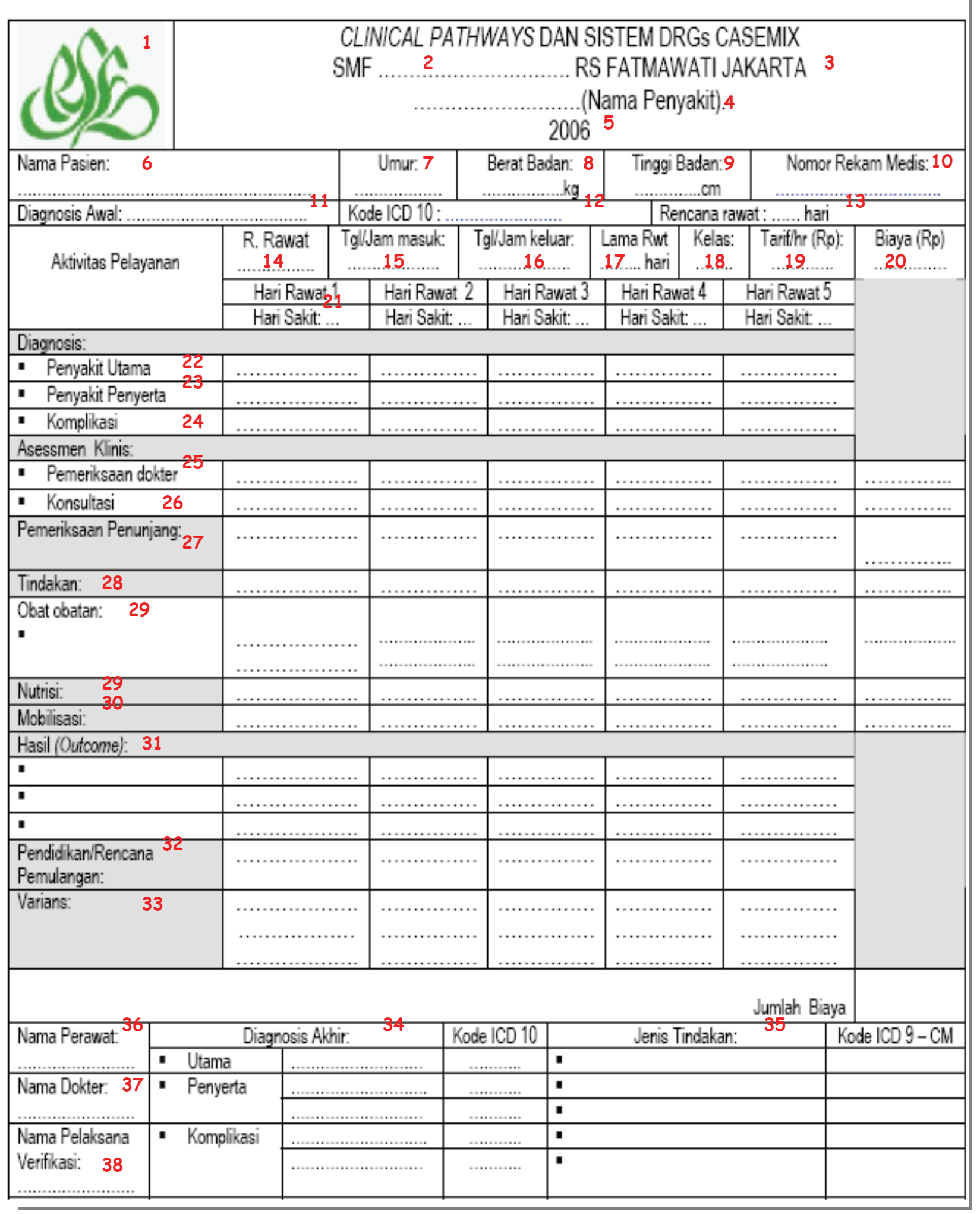


Keterangan

\begin{tabular}{ll}
\hline No & Penjelasan \\
\hline 1. & Lambang atau Logo Rumah Sakit \\
2. & Nama SMF atau Departemen yang membuat \\
3. Nama Rumah Sakit \\
4. Nama Judul/Topik penyakit
\end{tabular}

Dapat dicantumkan juga kode Rumah Sakit

Dapat juga diagnosis kerja saat masuk, contoh:

1. Observasi Febris

2. Observasi Kejang dsb

Ditulis oleh SMF terkait.

Bila perlu dapat ditulis nomor dan revisi.

Diisi oleh perawat dinas.

Untuk bayi dalam bulan, untuk neonatus dalam hari.

Untuk berat di bawah $10 \mathrm{~kg}$ ditulis dalam satuan gram.

Untuk bayi dan noenatus panjang badan (sentimeter).

Diisi oleh perawat dinas.

Diisi oleh dokter SMF terkait.

Diisi oleh dokter SMF terkait.

Hari rawat rerata dapat diperoleh dari data morbiditas rumah sakit (RL2a dan 2b) atau kesepakatan/ konsensus seluruh profesi di SMF.

Diisi oleh dokter SMF terkait.

Ditulis nomor kamar, diisi oleh perawat dinas.

14. Ruang Rawat: nama ruangan perawatan Diisi oleh perawat dinas.

Diisi oleh perawat dinas.

Diisi oleh perawat dinas.

Diisi oleh perawat dinas.

Diisi oleh perawat dinas.

Diisi oleh petugas yang diberi kewenangan.

Diisi oleh perawat dinas.

Diisi oleh dokter SMF terkait.

Diisi oleh dokter SMF terkait.

Diisi oleh dokter SMF terkait.

Diisi oleh dokter SMF terkait.

Diisi oleh dokter SMF terkait.

Diisi oleh dokter SMF terkait.

Diisi oleh dokter SMF terkait.

Diisi oleh dokter SMF terkait. 
30. Ditulis seluruh kegiatan mobilisasi kepada pasien.

31. Ditulis seluruh gejala klinis, obat, tindakan operasi dan hasil pemeriksaan penunjang yang menjadi indikator dalam monitoring (follow up) pasien.

32. Ditulis seluruh kegiatan pendidikan, penyuluhan maupun rencana pulang.

33. Ditulis seluruh deviasi dari rencana: diagnosis, klinis, pemeriksaan penunjang, tindakan, obat, nutrisi, mobilisasi dan pendidikan/penyuluhan/rencana pemulangan.

34. Ditulis seluruh diagnosis utama, penyerta dan komlikasi sesuai dengan Kode diagnosis ICD 10.

35. Ditulis seluruh tindakan yang dilakukan terhadap pasien sesuai Kode Tindakan Prosedur ICD 9 CM

36. Ditulis nama lengkap perawat.

37. Nama lengkap/ kode dokter yang merawat.

38. Ditulis nama petugas yang diberi kewenangan untuk melakukan verifikasi biaya.
Diisi oleh perawat dinas dan atau petugas rehabilitasi medis.

Diisi oleh dokter SMF terkait.

Diisi oleh dokter SMF terkait dan perawat dinas.

Varians tersebut dianalisis dan dilakukan

audit medis maupun audit manajerial.

Dilakukan oleh dokter SMF terkait dan

atau perawat dinas sesuai kapasitas kewenangannya.

Diisi oleh dokter SMF terkait dan atau

perawat dinas sesuai kapasitas kewenangannya.

Diisi oleh dokter SMF terkait dan atau

perawat dinas sesuai kapasitas

kewenangannya.

Diisi oleh perawat dinas.

Diisi oleh dokter SMF terkait.

Diisi oleh petugas yang diberi kewenangan untuk melakukan verikasi biaya.
Dalam pelaksanaan tahap kodefikasi diagnosis ICD 10 dan prosedur tindakan ICD 9 CM yang dilakukan oleh Bagian Rekam Medik sebagai Unit Coding Panitia Casemix RS Fatmawati, Komite Medik RS Fatmawati melakukan analisis dan deteksi validitas data tersebut. Bila data tersebut 'dubious', akan dikembalikan untuk klarifikasi; bila ada laporan data ketidaklengkapan akan disampaikan kepada individu dokter melalui Ketua SMF masing masing, bila ada 'curiousity' dan atau 'suspicious' akan ditindaklanjuti melalui Tim Tim terkait di Komite Medik dan bila perlu dapat disampaikan dalam agenda Sidang Pleno Komite Medik yang diadakan setiap hari Senin jam 12.30 - 13. 30 WIB. Berdasarkan hasil analisis data tersebut Ketua Komite Medik mendapatkan ide masukan bahwa kodefikasi ICD 10 dan ICD 9 CM tersebut dapat dipergunakan sebagai salah satu alat indikator untuk monitoring dan bahan cross check untuk proses audit medis lebih lanjut sesuai Panduan Audit Medis Komite Medik melalui Tim Etik dan Mutu Profesi 2,31,32(Gambar 2).

Setiap rumah sakit membuat dan mengirimkan secara berkala sesuai dengan jenis formulirnya masing masing (RL 1 sampai RL 6) sesuai dengan dengan Buku Petunjuk Pengisian, Pengolahan dan Penyajian Data Rumah Sakit ${ }^{34}$ sebagaimana berikut:
1. Data Kegiatan Rumah Sakit (Formulir RL 1) setiap triwulan

2. Data Keadaan Morbiditas Pasien (Formulir RL 2) setiap triwulan:
a. Morbiditas Rawat Inap (Formulir RL 2a)
b. Morbiditas Rawat Jalan (Formulir RL 2b)
c. Morbiditas Rawat Inap Surveilans Terpadu RS (Formulir RL 2a1)
d. Morbiditas Rawat Inap Surveilans Terpadu RS (Formulir RL 2b1)
e. Status Imunisasi (Formulir RL 2c)
f. Individual Morbiditas Pasien Rawat Inap (Formulir RL 2.1, RL 2.2 dan RL 2.3)

3. Data Dasar Rumah Sakit (RL 3) setiap akhir tahun

4. Data Keadaan Ketenagaan Rumah Sakit (Formulir RL 4) setiap semester (6 bulan)

5. Data Peralatan Medik Rumah Sakit dan Data Kegiatan Kesehatan Lingkungan Rumah Sakit (Formulir RL 5) setiap akhir tahun

6. Data Infeksi Nosokomial Rumah Sakit (Formulir RL 6) setiap bulan.

Maka khusus untuk proses pengolahan data, Ketua Komite Medik RS Fatmawati menggabungkan skema pendekatan menjadi sebagaimna tertera dalam Gambar 3. 
Laporan Data bulanan dari Bagian Rekam Medik RSF:

1. Kelengkapan Rekam Medik

2. Morbiditas dan Mortalitas

3. 10 Penyakit Terbesar Rawat Jalan untuk setiap poliklinik SMF

4. 10 Penyakit Terbesar Rawat Jalan untuk setiap SMF

5. 10 Sebab Kematian untuk setiap SMF

6. Laporan Data Tindakan Operasi

Ketua Komite Medik

1. Analisis Data

2. Deteksi data

a. 'dubious'

b. 'curious

c. 'suspicious'

3. Feed Back Hasil Analisis Data

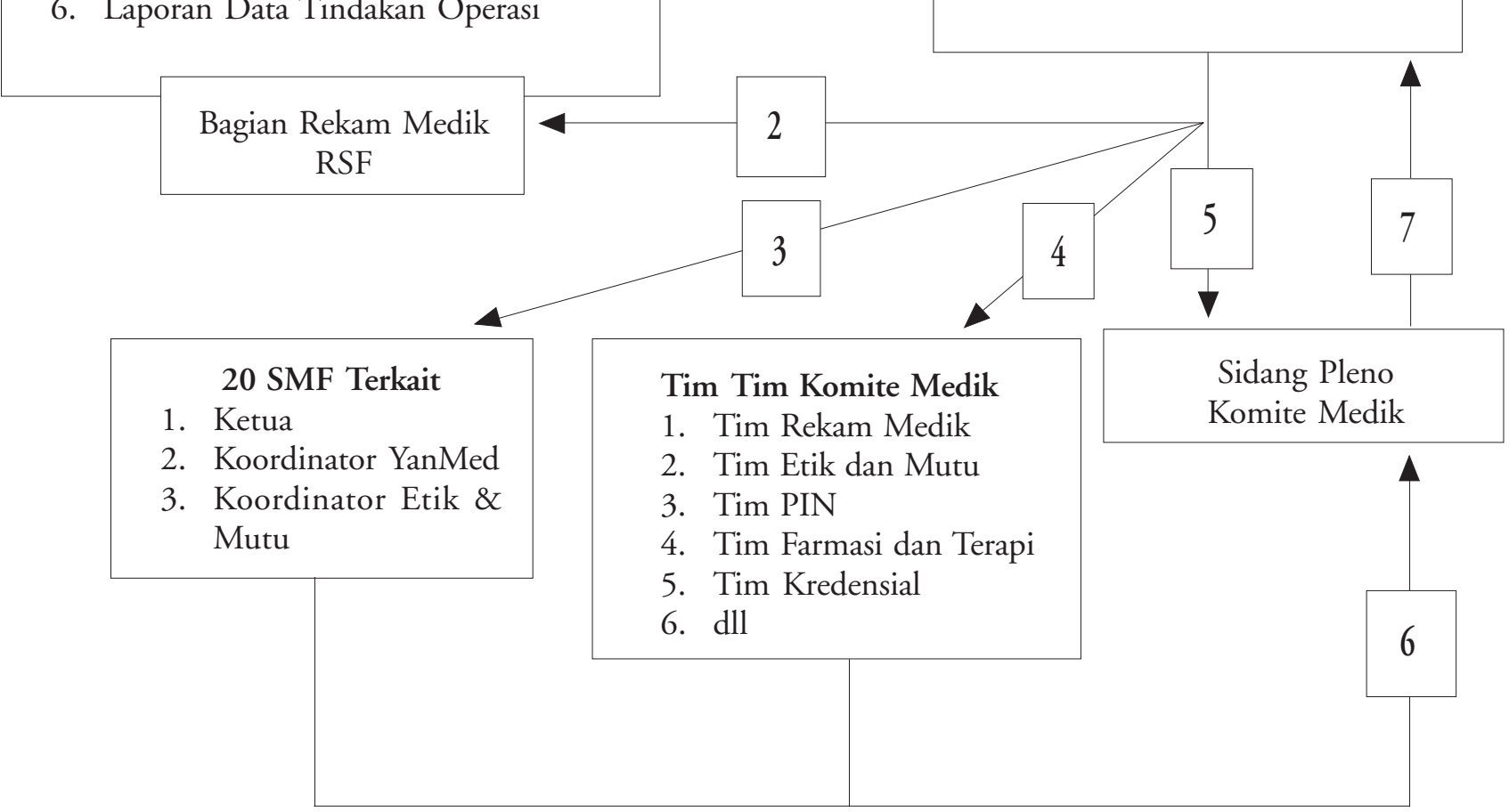

Gambar 2. Alur proses mekanisme data dan umpan balik (feed back $)^{33}$

\section{Format Umum Clinical Pathways}

Langkah selanjutnya adalah mengkaji dan mendesain Format Umum Clinical Pathways sebagai 'template' untuk setiap profesi untuk membuat clinical pathways masing masing sesuai dengan bidang keahliannya dan melibatkan multidisiplin profesi medis, keperawatan dan farmasis/apoteker sebagai contoh tertera pada Gambar 4.

Dalam kolom obat obatan harus sesuai dengan yang dari Standar Formularium Rumah Sakit (Gambar 4) yang telah disusun oleh Tim Farmasi dan Terapi Rumah Sakit. Penyimpangan (deviasi) obat obatan (jenis, dosis dan cara pemberian) dapat diperkenankan bila memang diperlukan setelah mengisi Formulir Lampiran 1 Formularium Rumah Sakit Edisi III 2003 (Gambar 5) dan harus dicatat dalam kolom varians serta dapat dipertanggungjawabkan melalui audit medis tingkat pertama ( $1^{\text {st }}$ party medical audit) sebagaimana dalam Form 1 Audit Medis sebagai salah satu unsur dari variance tracking.

SMF Kesehatan Anak RS Fatmawati dengan seluruh SubBagian (Divisi) telah menyusun buku mengenai Clinical Pathways dalam rangka implementasi Sistem Casemix sebagaimana tertera dalam Gambar 6. 


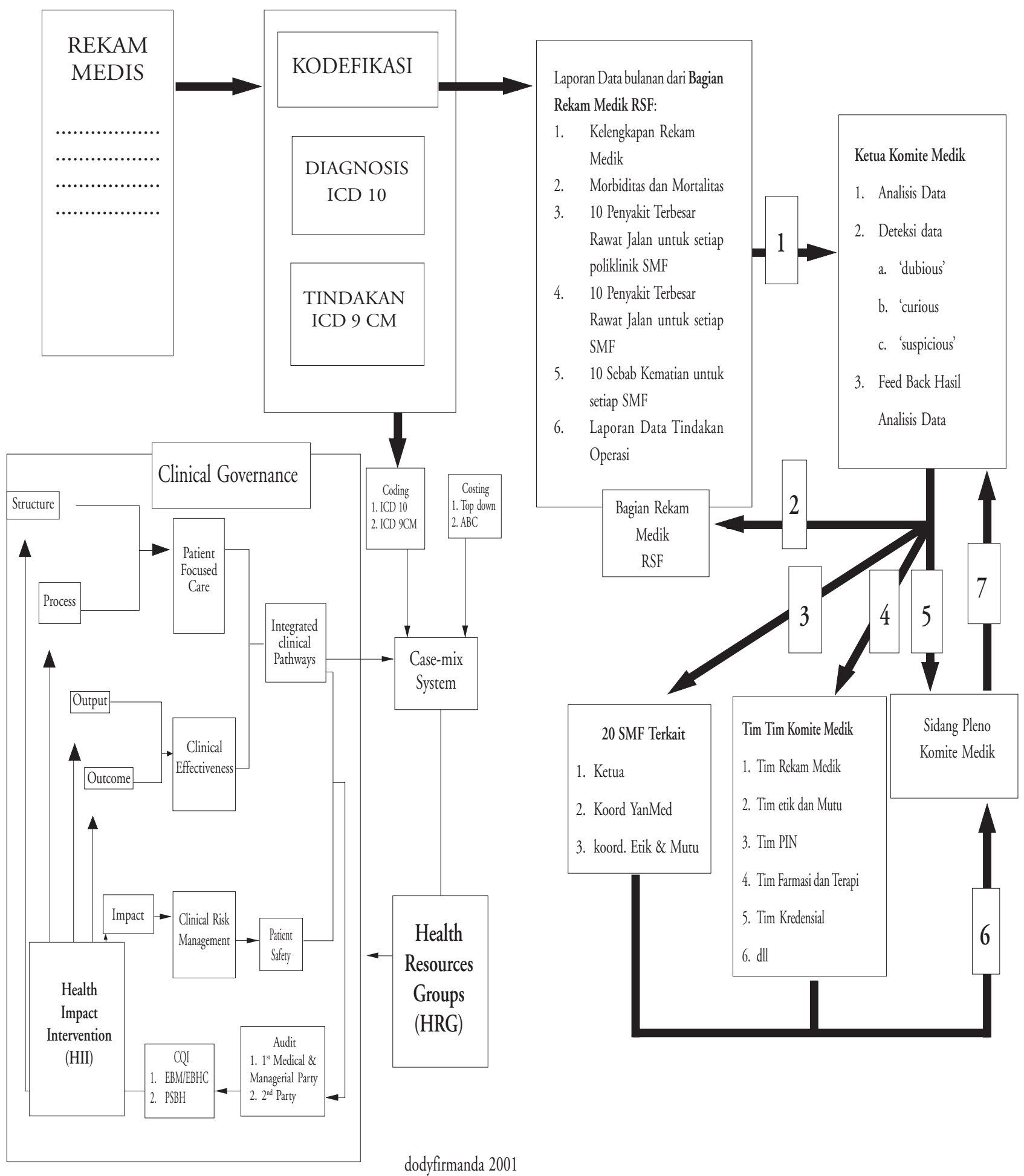

Gambar 3. Skema pendekatan dalam proses pengolahan data untuk penyusunan Clinical Pathways. ${ }^{26}$ 


\section{Format Umum Clinical Pathways}

\begin{tabular}{|c|c|c|c|c|c|c|c|c|c|c|c|}
\hline$y$ & & & & $\begin{array}{l}\text { CL/ } \\
\text { SMF }\end{array}$ & $\begin{array}{r}1 C A L \\
\ldots\end{array}$ & $\begin{array}{l}\mathrm{ATH} \\
\ldots \ldots\end{array}$ & $\begin{array}{l}\text { AYS } \\
\ldots \ldots \\
\cdots\end{array}$ & $\begin{array}{r}0 \mathrm{DN} S \mathrm{SI} \\
\mathrm{RS} \\
\ldots \ldots(\mathrm{N} \\
2006\end{array}$ & $\begin{array}{l}\text { ISTEM DRGs C } \\
\text { FATMAWATI } \\
\text { dama Penyakit). }\end{array}$ & $\begin{array}{l}\text { ASEMIX } \\
\text { JAKARTA }\end{array}$ & \\
\hline Nama Pasien: & & & & & Umur: & & $\begin{array}{l}\text { Berat Ba } \\
\ldots \ldots \ldots \ldots \ldots\end{array}$ & dan: & $\begin{array}{l}\text { Tinggi Badan: } \\
\end{array}$ & Nomor $\mathrm{F}$ & Rekam Medis: \\
\hline Diagnosis Awal: & & & & Kod & e ICD 10: & & & & \begin{tabular}{l|l} 
& Rencana $\mathrm{r}$ \\
\end{tabular} & rawat:....... hari & \\
\hline Aktivitas Pela & anan & R. P & wat & $\begin{array}{c}\mathrm{Tg} / \mathrm{J} \\
\ldots \ldots\end{array}$ & am masuk & & glivam ke & Iuar: & 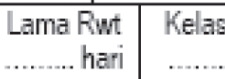 & \begin{tabular}{l|c} 
8: & Tarffhr (Rp) \\
.. &
\end{tabular} & $\begin{array}{l}\text { Biaya }(\mathrm{Rp}) \\
\ldots\end{array}$ \\
\hline & & & Rawat 1 & & Hari Rav & vat 2 & Hari $R$ & awat 3 & Hari Rawat 4 & Hari Rawat 5 & \\
\hline & & & Sakit: ... & & Hari Sak & & Hari S & akit: ... & Hari Sakit: ... & Hari Sakit: ... & \\
\hline Diagnosis: & & & & & & & & & & & \\
\hline - Penyakit Utan & & $\ldots \ldots$ & $\ldots$ & & …....... & $\ldots \ldots$ & $\ldots \ldots \ldots$ & ב....... & 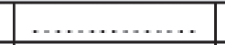 & (n............ & \\
\hline - Penyakit Peny & & $\cdots$ & $\ldots \ldots$ & & $\ldots$ & $\ldots$. & 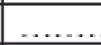 & $\ldots \ldots$ & $\ldots \ldots \ldots$ & , $\ldots \ldots \ldots$ & \\
\hline - Komplikasi & & ..... & $\ldots \ldots \ldots$ & & $\ldots \ldots \ldots$ & ........ & $\ldots \ldots \ldots$ & $\ldots \ldots \ldots$ & & & \\
\hline Asessmen Kliris: & & & & & & & & & & & \\
\hline - Pemeriksaan & kter & $\ldots \ldots$ & $\ldots \ldots \ldots$ & & .......... & ....... & $\ldots \ldots \ldots$ & $\ldots \ldots \ldots$ & ............... & $\ldots \ldots \ldots \ldots \ldots$ & 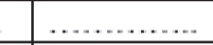 \\
\hline - Konsultasi & & $\ldots \ldots$ & $\ldots \ldots \ldots$ & & $\ldots \ldots \ldots$ & $\ldots \ldots$ & $\ldots \ldots \ldots$ & f....... & ............... & .............. & $\ldots \ldots \ldots \ldots \ldots$ \\
\hline Pemeriksaan Pen. & jang: & $\cdots$ & 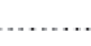 & & $\ldots$. & .... & $\ldots$ & 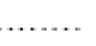 & $\ldots \ldots \ldots \ldots \ldots$ & ….......... & \\
\hline Tindakan: & & & & & & & & & & ........... & \\
\hline Obat obatan: & & $\ldots \ldots$ & ........... & & … & $\ldots \ldots$ & & & $\cdots$ & $\cdots \cdots$ & ....... \\
\hline Nutrisi: & & & & & & & & & & & \\
\hline Mobilisasi: & & $\ldots \ldots$ & $\ldots$. & & $\ldots$ & ...... & $\ldots$ & & $\ldots$. & 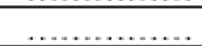 & \\
\hline Hasil (Outcome): & & & & & & & & & & & \\
\hline - & & $\ldots \ldots$ & $\ldots \ldots \ldots$ & & $\ldots \ldots \ldots$ & ...... & $\ldots \ldots \ldots$ & ........ & $\ldots \ldots \ldots \ldots \ldots$ & 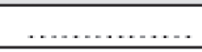 & \\
\hline 1 & & $\ldots \ldots$ & $\ldots \ldots \ldots$ & & .......... & $\ldots \ldots$ & $\ldots \ldots \ldots$ & ........ & ............... & .............. & \\
\hline - & & $\ldots$ & $\cdots$ & & $\therefore$ & $\ldots$ & & & & & \\
\hline $\begin{array}{l}\text { PendidikaniRenca } \\
\text { Pemulangan: }\end{array}$ & & & & & & & & & & & \\
\hline Varians: & & $\begin{array}{l}\cdots \\
\cdots\end{array}$ & , & & $\cdots \cdots$ & $\cdots$ & $\begin{array}{ll}\ldots \ldots \\
\cdots \cdots\end{array}$ & $\begin{array}{l}\cdots \\
\cdots \cdots \\
\cdots\end{array}$ & $\begin{array}{l}\ldots \ldots \ldots \ldots \ldots \\
\ldots \ldots \ldots \ldots \ldots \ldots\end{array}$ & $\begin{array}{l}\ldots \ldots \ldots \ldots \ldots \\
\ldots \ldots \ldots \ldots \ldots \ldots \ldots \\
\end{array}$ & \\
\hline & & & & & & & & & & Jumlah Biaya & \\
\hline Nama Perawat: & & Dia & osis Akh & & & Kode & $\operatorname{ICD} 10$ & & Jenis Tindakar & & Kode ICD 9-CM \\
\hline & & Utama & & & & & & - & & & \\
\hline Nama Dokter: & 1 & Penyerta & $\ldots$ & 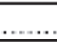 & $\ldots .$. & & & - & & & \\
\hline & & & & & & & & - & & & \\
\hline Nama Pelaksana & " & Komplikasi & & & & & & 1 & & & \\
\hline Verifkasi: & & & $\ldots \ldots$. & & & & & - & & & \\
\hline
\end{tabular}

Gambar 4. Format Umum Clinical Pathways yang telah disepakati bersama dalam Sidang Pleno Komite Medik untuk seluruh 20 SMF di RS Fatmawati. ${ }^{7}$ 


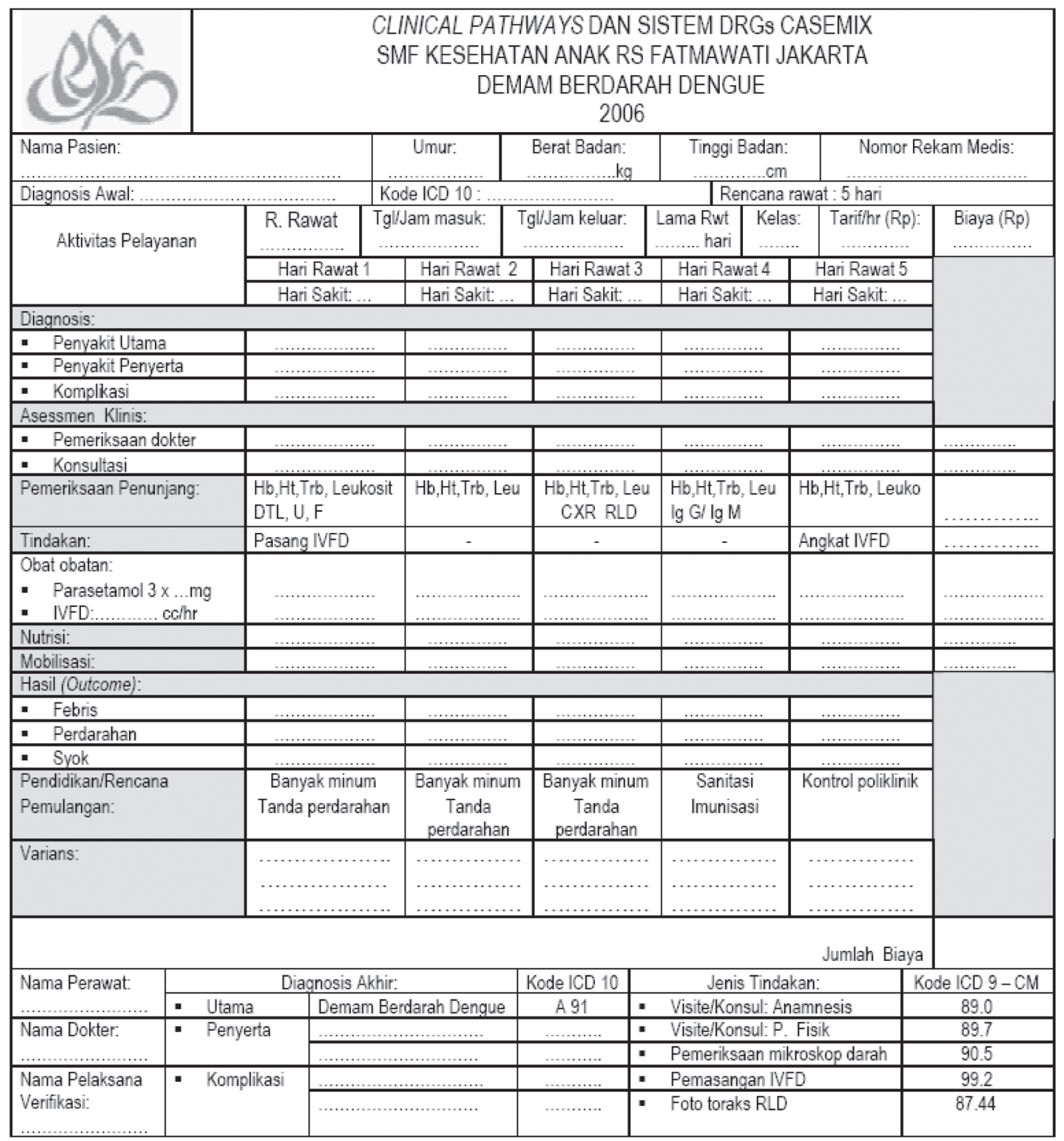

Gambar 5. Clinical Pathways untuk Demam Berdarah Dengue dari Buku Clinical Pathways SMF Kesehatan Anak RS Fatmawati Edisi 2006. ${ }^{37}$ 


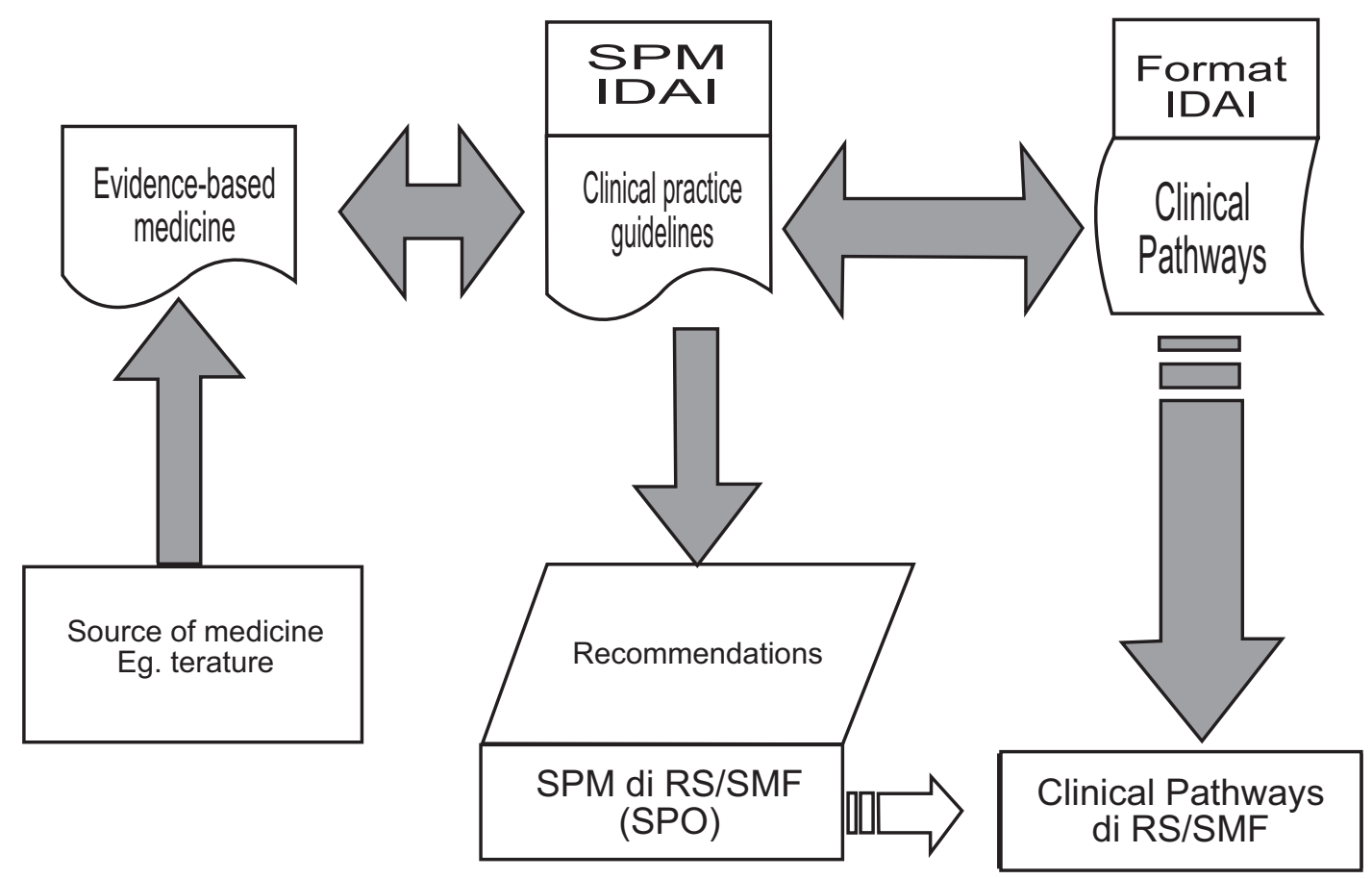

Gambar 6. Skema ringkas peran organisasi profesi IDAI dalam mempersiapkan SPM dan format Clinical Pathways Kesehatan Anak.

\section{Hubungan Clinical Pathways dengan Mutu Profesi (Quality)}

Implementasi $\mathrm{CP}$ sangat erat berhubungan dan berkaitan dengan Clinical Governance dalam rangka menjaga dan meningkatkan mutu pelayanan dengan biaya yang dapat diestimasikan dan terjangkau, ${ }^{38-45}$ sebagaimana tertera dalam Gambar 1. Sedangkan secara sederhana clinical governance adalah suatu cara (sistem) upaya menjamin dan meningkatkan mutu pelayanan secara sistematis dalam satu organisasi penyelenggara pelayanan kesehatan (rumah sakit) yang efisien. ${ }^{1,2,46}$

Catatan: Istilah 'Clinical governance' itu sendiri yang berasal dari negara Inggris. 'Clinical governance' ini merupakan salah satu sumbang saran BAMM (British Association of Medical Manager) yang berhasil dan diterima oleh pemerintah (Labour Party) setelah melalui perdebatan publik akibat beberapa kasus pelayanan kesehatan/kedokteran yang muncul ke permukaan menjadi sorotan dan tuntutan masyarakat serta merupakan kasus untuk CNST - Clinical Negligence Scheme for the Trusts - ('risk management'). Meskipun sebelumnya telah mempunyai beberapa program pendekatan dalam upaya peningkatan mutu melalui - (Small) Hospitals Accreditation, Patients' Charter, BSI 5751/ISO 9002, Quality Assurance, maupun TQM. Pada tahun 1997 bertepatan dengan peluncuran kebijakan baru dalam penyelenggaraan pelayanan kesehatan oleh NHS (National Health Services) dan recana kerjanya untuk 10 tahun mendatang - A First Class Service: Quality in the new $N H S$ - dalam rangka meningkatkan mutu pelayanan kesehatan (kedokteran) serta sekaligus mengantisipasi ('bidden agenda' - for the unpicking process) era pasar terbuka Masyarakat Ekonomi Eropa/EEC.47,48

Clinical Pathways (CP) merupakan salah satu komponen dari Sistem DRG-Casemix yang terdiri dari kodefikasi penyakit dan prosedur tindakan (ICD 10 dan ICD 9-CM) dan perhitungan biaya (baik secara top down costing atau activity based costing maupun kombinasi keduanya). ${ }^{7,89} \mathrm{CP}$ dapat digunakan sebagai alat (entry point) untuk melakukan audit medis dan manajemen baik untuk tingkat pertama maupun kedua ( $1^{\text {st }}$ party and $2^{\text {nd }}$ party audits) dalam rangka menjaga dan meningkatkan mutu pelayanan. ${ }^{49-53} \mathrm{CP}$ dapat digunakan juga sebagai salah satu alat mekanisme evaluasi penilaian risiko untuk mendeteksi kesalahan 
aktif (active errors) dan laten (latent/system errors) maupun nyaris terjadi (near miss) dalam Manajemen Risiko Klinis (Clinical Risk Management) dalam rangka menjaga dan meningkatkan keamanan dan keselamatan pasien (patient safety). ${ }^{54-55}$

Ilustrasi contoh dimana Clinical Pathways dapat mengubah/revisi Standar Pelayanan Medis (SPM)/ Standar Prosedur Operasional (SPO) dalam penatalaksanaan pasien di ruangan berdasarkan kaidah Evidence-based Medicine (EBM) yakni tentang pemberian vitamain $\mathrm{K}_{1}$ kepada bayi baru lahir. ${ }^{1}$

\section{Peran Organisasi Profesi IDAI}

Secara ringkas peran profesi IDAI sangat strategis dan penting dalam mempersiapkan anggotanya untuk lebih meningkatkan profesionalisme dalam mutu pelayanan keprofesiannya melalui berbagai kegiatan ilmiah (skill dan knowledge) dalam rangka mempertahankan dan meningkatkan kompetensi keprofesian sesuai dengan Standar Profesi IDAI. Unit Kelompok Kerja (UKK) sebagai brainware mempersiapkan modul modul dari kurikulum pendidikan dokter spesialis anak (dan konsultan) dari segi aspek pendidikan dan dari segi aspek pelayanan keprofesian dengan mempersiapkan Standar Pelayanan Medis Kesehatan Anak dan Standar Formularium Anak sebagai acuan dalam praktik (clinical practice guidelines) serta format pelaksanaannya dalam bentuk Clinical Pathways. Ketiga hal tersebut merupakan input bagi setiap anggota IDAI dalam implementasi melaksanakan praktik keprofesiannya baik sebagai perorangan maupun kelompok.

\section{Daftar Pustaka}

1. Keputusan Menteri Kesehatan RI No. 496/Menkes/SK/ IV/2005 tentang Pedoman Audit Medis di Rumah Sakit.

2. Firmanda D. Clinical Governance: Konsep, konstruksi dan implementasi manajemen medik. Disampaikan pada seminar dan business meeting "Manajemen Medis: dari Kedokteran Berbasis Bukti (Evidence-based Medicine/ EBM) menuju Clinical Governance” dalam rangka HUT RSUP Fatmawati ke 40 di Gedung Bidakara Jakarta 30 Mei 2000.

3. Firmanda D. Professional continuous quality improvement in health care: standard of procedures, clinical guidelines, pathways of care and evidence-based medi- cine. What are they? J Manajemen \& Administrasi Rumah Sakit Indonesia 1999; 1(3): 139-144.

4. Firmanda D. Dari penelitian ke praktik kedokteran. Dalam Sastroasmoro S dan Ismael S. Dasar dasar metodologi penelitian klinis. Edisi ke-2. Jakarta: Sagung Seto, 2002.

5. Firmanda D. Clinical governance dan aplikasinya di rumah sakit. Disampaikan pada Pendalam-an materi rapat kerja RS Pertamina Jaya, Jakarta 29 Oktober 2001.

6. Firmanda D. Professional CQI: from Evidence-based Medicine (EBM) towards Clinical Governance. Presented at the plenary session in World IPA, Beijing 23rd July 2001.

7. Komite Medik RS Fatmawati. Sistem Komite dan Sistem SMF di RS Fatmawati Jakarta 2003.

8. Firmanda D. Pedoman Penyusunan Clinical Pathways dalam rangka implementasi Sistem DRGs Casemix di rumah sakit. Disampaikan dalam Sidang Pleno Komite Medik RS Fatmawati, Jakarta 7 Oktober 2005.

9. Firmanda D. Key to success of quality care programs: empowering medical professional. Global Health Journal 2000; 1(1) http://www.interloq.com/a26.htm

10. Firmanda $\mathrm{D}$. The pursuit of excellence in quality care: a review of its meaning, elements, and implementation. Global Health Journal 2000;1(2) http://www.interloq. com/a39vlis2.htm

11. Firmanda D. Total quality management in health care (Part One). Indones J Cardiol Pediatr 1999; 1(1):43-9.

12. Firmanda D. Editorial: Profesionalisme. Medicinal 2000; $1(1): 6$.

13. Rumah Sakit Fatmawati. Kebijakan tentang Penerimaan Pasien Rawat Inap (Admission) Nomor Dokumen HK.00.07.1.256 tanggal 15 September 2003 dengan Nomor Revisi HK.00.07.1.201 tanggal 10 Mei 2005.

14. Rumah Sakit Fatmawati. Prosedur tentang Penerimaan Pasien Rawat Inap (Admission) Nomor Dokumen HK.00.07.1.257 tanggal 15 September 2003 dengan Nomor Revisi HK.00.07.1.202 tanggal 10 Mei 2005.

15. Rumah Sakit Fatmawati. Kebijakan tentang Program Pilih Dokter. Nomor Dokumen HK.00.07.1.49 tanggal 28 Februari 2003.

16. Rumah Sakit Fatmawati. Prosedur tentang Program Pilih Dokter. Nomor Dokumen HK.00.07.1.49 tanggal 28 Februari 2003.

17. Komite Medik RS Fatmawati. Standar Pelayanan Medis 20 SMF di RS Fatmawati Jakarta 2003.

18. Firmanda D. Pedoman Audit Medis Komite Medik RS Fatmawati. Jakarta 1999. 
19. Firmanda D. Pelaksanaan Audit Medik. Disampaikan dalam Semiloka Pelaksanaan Audit Medik di RSUD Dr. Soetomo, Surabaya pada tanggal 11 Desember 2003.

20. Firmanda D. Pengalaman Komite Medis RS Fatmawati dalam melaksanakan Audit Medis. Disampaikan dalam Temu Karya I: Implementasi Good Clinical Governance di bidang Pelayanan Medis, Jakarta 27 September 2004.

21. Keputusan Menteri Kesehatan RI No. 496/Menkes/SK/ IV/2005 tentang Pedoman Audit Medis di Rumah Sakit.

22. Firmanda D. Panduan Manajemen Risiko Klinis dan Keamanan/Keselamatan Pasien (Clinical Risks Management and Patient Safety) Komite Medik RS Fatmawati, Jakarta 2005.

23. Firmanda D. Panduan Health Impact Intervention Komite Medik RS Fatmawati, Jakarta 2006.

24. Firmanda D. Pedoman Penyusunan Clinical Pathways dalam rangka implementasi Sistem DRGs Casemix di rumah sakit. Disampaikan dalam Sidang Pleno Komite Medik RS Fatmawati, Jakarta 7 Oktober 2005.

25. Firmanda D. Clinical Pathways: Peran profesi medis dalam rangka menyusun Sistem DRGs Casemix di rumah sakit. Disampakan pada kunjungan lapangan ke RSUP Adam Malik Medan 22 Desember 2005, RSUP Hasan Sadikin Bandung 23 Desember 2005 dan Evaluasi Penyusunan Clinical Pathways dalam rangka penyempurnaan Pedoman DRGs Casemix Depkes RI, Hotel Grand Cempaka Jakarta 29 Desember 2005.

26. Firmanda D, Pratiwi Andayani, Nuraini Irma Susanti, Srie Enggar KD dkk. Clinical Pathways Kesehatan Anak dalam rangka implementasi Sistem DRGs Casemix di RS Fatmawati, Jakarta 2006 (dalam pencetakan).

27. Firmanda D. Penyusunan dan Implementasi Clinical Pathways di Rumah Sakit. Disampaikan pada Sosialisasi Pedoman Clinical Pathways di Rumah Sakit. Diselenggarakan oleh Direktorat Jenderal Bina Pelayanan Medik Depkes RI di Hotel Permata Bidakara, Bandung 4 Juli 2006.

28. European Pathways Association (EPA). Slovenia Board Meeting, December 2005.

29. Firmanda D. Kodefikasi ICD 10 dan ICD 9 CM: indikator mutu rekam medik dalam rangka meningkatkan mutu pelayanan rumah sakit. Disampaikan pada Sosialisasi Pola Sistem Informasi Manajemen Rumah Sakit. Diselenggarakan oleh Direktorat Jenderal Bina Pelayanan Medik Depkes RI di Hotel Panghegar Bandung 1-3 Juni 2006.

30. Departemen Kesehatan RI. Buku Petunjuk Pengisian, Pengolahan dan Penyajian Data Rumah Sakit. Direktorat Jenderal Bina Pelayanan Medik Depkes RI, Jakarta 2005.
31. Firmanda D. Audit Medis di Rumah Sakit. Disampaikan dalam Sosialisasi Pedoman Audit Medik di Rumah Sakit, diselenggarakan oleh Dirjen Bin Yan Medik DepKes RI, Cisarua 7 September 2005.

32. Fimanda D. Audit Medis di Rumah Sakit. Disampaikan pada Hospital Management Refreshing Course and Exhibition (HMRCE): Change Management in Healthcare Services. Diselenggarakan oleh Perhimpunan Manajer Pelayanan Kesehatan Indonesia (PERMAPKIN) di Hotel Borobudur, Jakarta 21 - 23 Februari 2006.

33. Komite Medik RS Fatmawati. Sistem Komite Medik dan Sistem SMF di RS Fatmawati, Jakarta 2003.

34. Departemen Kesehatan RI. Buku Petunjuk Pengisian, Pengolahan dan Penyajian Data Rumah Sakit. Direktorat Jenderal Bina Pelayanan Medik Depkes RI, Jakarta 2005.

35. Firmanda D. ICD 10 dan ICD 9 CM: sebagai indikator mutu rekam medik dalam rangka meningkatkan mutu pelayanan rumah sakit. Disampaikan pada Sosialisasi Pola Sistem Informasi Manajemen Rumah Sakit. Diselenggarakan oleh Direktorat Jenderal Bina Pelayanan Medik Depkes RI di Hotel Panghegar Bandung 1-3 Juni 2006.

36. Firmanda D. Pelaksanaan audit medik di rumah sakit. Disampaikan pada Pertemuan Komite Medik Rumah Sakit. Diselenggarakan oleh Dinas Kesehatan Propinsi Jawa Barat di Hotel Permata Bidakara, Bandung $30 \mathrm{Mei}$ 2006.

37. Firmanda D, Pratiwi Andayani, Nuraini Irma Susanti, Srie Enggar KD dkk. Clinical Pathways Kesehatan Anak dalam rangka implementasi Sistem DRGs Casemix di RS Fatmawati, Jakarta 2006.

38. Campbell $\mathrm{H}$ et al. Clinical pathways. BMJ 1998: 316;133-4.

39. Johnson S. Pathways of care. Blackwell Science, Oxford 1997.

40. Edwards J. Clinical Care Pathways: a model for effective delivery of health care? J of Integrated Care 1998:2; 59-62

41. Hale C. Case Management and Managed Care. Nursing Standard 1995: 9(19); 33-5

42. Kitchener D et al. Integrated Care Pathways; Effective Tools for Continuous Evaluation of Clinical Practice. J Evaluation in Clinical Practice 1996:2(1); 65-9

43. Petryshen PR, Petryshen PM. The case management model: an approach to the delivery of patient care. J Advance Nursing 1992:17;1188-94

44. Wall M. Managed Care: Development of an Integrated Care Pathway in Neurosciences. NT Research 1997: 2(4); 290-1 
45. Wilson J, Integrated Care Management: The Pathway to Success? Oxford Butterworth Heimeman 1997

46. Firmanda D. The pursuit of excellence in quality care: a review of its meaning, elements, and implementation. Global Health Journal 2000;1(2) http://www.interloq. com/a39vlis2.htm

47. British Department of Health. Clinical Governance: Quality in the New NHS. London: NHS Executive, 1999.

48. Scally G, Donaldson LJ. The NHS's 50 anniversary. Clinical governance and the drive for quality improvement in the new NHS in England. BMJ. 1998 Jul 4;317(7150):61-5.

49. Firmanda D. Pedoman Audit Medis. Komite Medis RS Fatmawati Jakarta 2003.

50. Firmanda D. Pedoman Audit Medis di Rumah Sakit. Disampaikan di RSUD Dr. Soetomo, Surabaya 2003.

51. Firmanda D. Pedoman Audit Medis di Rumah Sakit. Disampaikan dalam rangka Penyusunan dan Penyempurnaan Pedoman Audit Medis di Rumah Sakit. Depkes RI, Jakarta 2004.
52. Keputusan Menteri Kesehatan RI Nomor 496/Menkes/ SK/IV/2005 tentang Pedoman Audit Medis di Rumah Sakit.

53. Firmanda D. Key to success of quality care programs: empowering medical professional. Global Health Journal 2000; 1(1) http://www.interloq.com/a26.htm

54. Firmanda D. Pedoman dan Instrumen Manajemen Risiko Klinis dan Keamnan Pasien (Clinical Risks Management and Patients Safety). Pleno Komite Medik RS Fatmawati 21 Juni 2005.

55. Firmanda D. Instrumen Manajemen Risiko Klinis dan Keamanan Pasien (Clinical Risks Management and Patients Safety). Disampaikan dalam rangka penyusunan dan penyempurnaan Instrumen Manajemen Risiko Klinis dan Keamanan Pasien (Clinical Risks Management and Patients Safety) dan uji coba di 4 propinsi di Depkes RI Jakarta 2005.

56. American Academy of Pediatrics. Policy Statement Controversies concernng Vitamin $\mathrm{K}$ and the newborn. Pediatrics 2003;112(1):191-2. 